(C) 2022, The Authors. Published by Elsevier Inc. and Fass Inc. on behalf of the American Dairy Science Association ${ }^{\circledR}$. This is an open access article under the CC BY license (http://creativecommons.org/licenses/by/4.0/).

\title{
Kinetics of pepsin-induced hydrolysis and the coagulation of milk proteins
}

\author{
Mengxiao Yang, ${ }^{1,2} \odot$ Aiqian Ye, ${ }^{1,2 *} \odot$ Zhi Yang, ${ }^{3} \odot$ David W. Everett, ${ }^{1,4} \odot$ Elliot Paul Gilbert, ${ }^{5,6} \odot$ \\ and Harjinder Singh ${ }^{1,2}$ \\ ${ }^{1}$ Riddet Institute, Private Bag 11 222, Palmerston North 4442, New Zealand \\ ${ }^{2}$ School of Food and Advanced Technology, Massey University, Private Bag 11 222, Palmerston North 4442, New Zealand \\ ${ }^{3}$ School of Food and Advanced Technology, Massey University, Auckland 0632, New Zealand \\ ${ }^{4}$ AgResearch Limited, Tennent Drive, Private Bag 11 008, Palmerston North 4442, New Zealand \\ ${ }^{5}$ Australian Centre for Neutron Scattering, ANSTO, New Illawarra Road, Lucas Heights, NSW 2234, Australia \\ ${ }^{6}$ Australian Institute for Bioengineering and Nanotechnology and Queensland Alliance for Agriculture and Food Innovation, \\ The University of Queensland, Brisbane, QLD 4072, Australia
}

\section{ABSTRACT}

Hydrolysis-induced coagulation of casein micelles by pepsin occurs during the digestion of milk. In this study, the effect of $\mathrm{pH}(6.7-5.3)$ and pepsin concentration $(0.110-2.75 \mathrm{U} / \mathrm{mL})$ on the hydrolysis of $\kappa$-casein and the coagulation of the casein micelles in bovine skim milk was investigated at $37^{\circ} \mathrm{C}$ using reverse-phase HPLC, oscillatory rheology, and confocal laser scanning microscopy. The hydrolysis of $\kappa$-casein followed a combined kinetic model of first-order hydrolysis and putative pepsin denaturation. The hydrolysis rate increased with increasing pepsin concentration at a given $\mathrm{pH}$, was $\mathrm{pH}$ dependent, and reached a maximum at $\mathrm{pH}$ $\sim 6.0$. Both the increase in pepsin concentration and decrease in $\mathrm{pH}$ resulted in a shorter coagulation time. The extent of $\kappa$-casein hydrolysis required for coagulation was independent of the pepsin concentration at a given $\mathrm{pH}$ and, because of the lower electrostatic repulsion between para-casein micelles at lower $\mathrm{pH}$, decreased markedly from $\sim 73 \%$ to $\sim 33 \%$ when $\mathrm{pH}$ decreased from 6.3 to 5.3. In addition, the rheological properties and the microstructures of the coagulum were markedly affected by the $\mathrm{pH}$ and the pepsin concentration. The knowledge obtained from this study provides further understanding on the mechanism of milk coagulation, occurring at the initial stage of transiting into gastric conditions with high $\mathrm{pH}$ and low pepsin concentration. Key words: pepsin, milk coagulation, rheology, microstructure, enzymatic hydrolysis kinetics

Received August 18, 2021.

Accepted October 17, 2021.

*Corresponding author: a.m.ye@massey.ac.nz

\section{INTRODUCTION}

Milk is an excellent source of nutrients for humans, providing proteins, fats, vitamins, and minerals (Haug et al., 2007). When milk transits into the gastric environment, gastric juice secretion is promoted, leading to the gradual decrease in milk $\mathrm{pH}$ from 6.7 to $\sim 2.0$ and the gradual increase in pepsin concentration from 0 to $\sim 2,000 \mathrm{U} / \mathrm{mL}$ (Gao et al., 2002; Minekus et al., 2014; Ye et al., 2016, 2017). Both in vitro and in vivo studies on the digestion of milk have found that the milk proteins coagulate at an early stage during gastric digestion, even though the pepsin concentration is low $(<5$ $\mathrm{U} / \mathrm{mL}$ ) and at $\mathrm{pH}>6$. As the coagulation occurs when the milk $\mathrm{pH}$ is still $>6$, which is far from the isoelectric point of casein proteins (pI 4.6), it is generally believed that this is induced by pepsin hydrolysis of the casein micelles (Boirie et al., 1997; Ye et al., 2016; Huppertz and Chia, 2021). The coagulum plays an important role in determining the gastric emptying rate, the release of nutrients, and the composition of the digesta emptied into the small intestine (Miranda and Pelissier, 1981; Ye et al., 2017; van Lieshout et al., 2020).

It is well known that $\mathrm{k}-\mathrm{CN}$ on the surface of the casein micelles provides steric and electrostatic stabilization (Payens, 1979). The action of pepsin on the casein micelles involves 3 distinct phases (Huppertz and Chia, 2021): (1) specific hydrolysis of the Phe ${ }^{105}-\mathrm{Met}^{106}$ bond of $\kappa$-CN by pepsin at $\mathrm{pH}>5$ yielding the $\mathrm{C}$-terminal glycosylated caseinomacropeptide and para- $\kappa-\mathrm{CN}$; (2) aggregation of casein micelles by hydrophobic association together with ionic electrostatic effects (Horne and Lucey, 2014), which occurs when a minimum amount of the caseinomacropeptide has been removed (a critical degree of hydrolysis); and (3) progressive proteolysis where both caseins and whey proteins are hydrolyzed into peptides at $\mathrm{pH}<4$ (Ye, 2021).

As the first 2 overlapping phases broadly resemble the mechanisms occurring in cheese manufacture, 
the coagulation of milk induced by pepsin could be similar to that induced by chymosin. Over the years, chymosin-initiated hydrolysis of $\kappa-\mathrm{CN}$ and the aggregation of the casein micelles in milk have been extensively studied (Dalgleish, 1980, 1988; van Hooydonk, 1987). Chaplin and Green (1980) demonstrated that chymosin hydrolyzes the $\mathrm{Phe}^{105}-\mathrm{Met}^{106}$ bond following the Michaelis-Menten equation, although, according to van Hooydonk (1987) and Jensen et al. (2015), a first-order rate equation describing enzymatic hydrolysis provides a better fit to the data. However, the kinetics of $\kappa-\mathrm{CN}$ hydrolysis catalyzed by pepsin in milk systems have not been fully elucidated. Carlson et al. (1987a) briefly reported on hydrolysis of $\kappa-\mathrm{CN}$ by pepsin with that by rennet, but the effects of the concentration of pepsin and the $\mathrm{pH}$ on $\mathrm{\kappa}$-CN hydrolysis have not been studied in detail.

After a minimum amount of $\kappa$-CN has been hydrolyzed, the casein micelles begin to aggregate (Dalgleish, 1979), leading to changes in the physicochemical properties of the milk which can be monitored using various techniques (Everett and Auty, 2008), such as confocal laser scanning microscopy (Auty et al., 1999), oscillatory rheology (Lucey et al., 2003), and diffusing wave spectroscopy (Sandra et al., 2007). Under in vitro gastric digestion conditions, it was reported that the coagulation of milk occurs at $\mathrm{pH}>6.2$, and a firm milk clot with a smooth surface is formed (Ye et al., 2017). In a recent study, the evolution of storage modulus $\left(\mathbf{G}^{\prime}\right)$ was monitored to investigate milk coagulation induced by glucono- $\delta$-lactone (GDL, used to obtain a gradual decrease in $\mathrm{pH}$ ) and porcine pepsin (Roy et al., 2020). These researchers found a decrease in the coagulation time (from 74.4 to $27.6 \mathrm{~min}$ ) and an increase in the coagulation $\mathrm{pH}$ (from 4.7 to 5.2 ) when the pepsin concentration increased from 5.03 to 23.71 (U/mg)/100 $\mathrm{mL}$ in milk. However, the rheological properties and the structural characteristics of the milk coagulum that is solely formed by pepsin-induced coagulation have not yet been investigated.

Therefore, to determine the relationship between hydrolysis and coagulation, this study examined the effects of the concentration of pepsin $(0.110-2.75 \mathrm{U} / \mathrm{mL}$ of milk) and $\mathrm{pH}$ (5.3-6.7) on protein hydrolysis and the aggregation characteristics of skim milk. The amount of para- $\kappa-\mathrm{CN}$ released by hydrolysis was determined by reverse-phase HPLC, and the rheological properties and microstructural characteristics of coagulum were examined using oscillatory rheology and confocal laser scanning microscopy, respectively. Using the above approach, an enhanced understanding was gained of the action of pepsin on $\kappa-\mathrm{CN}$ in fresh bovine skim milk.

\section{MATERIALS AND METHODS}

\section{Materials}

Fresh bovine whole milk was obtained from Dairy Farm 4 (Massey University, Palmerston North, New Zealand) and was skimmed by centrifugation with a swing bucket rotor (Thermo Fisher Scientific Multifuge Heraeus 3SR + centrifuge, Thermo Electron LED $\mathrm{GmbH})$ at $3,000 \times g$ and $4^{\circ} \mathrm{C}$ for $15 \mathrm{~min}$. The skim milk contains $0.12 \%$ fat, $4.31 \%$ protein, and $4.67 \%$ lactose as determined by a Milkoscan FT120 (Foss Electric). Sodium azide was added at a concentration of $0.02 \%$ (wt/vol) to act as a bacteriostatic agent. The $\mathrm{pH}$ of the skim milk samples was adjusted to $6.7,6.3,6.0$, 5.7 , or 5.3 at $20^{\circ} \mathrm{C}$ by the gradual addition of $1 \mathrm{M} \mathrm{HCl}$ under vigorous stirring conditions. The samples were stored at $4^{\circ} \mathrm{C}$, and small $\mathrm{pH}$ adjustments were made to achieve the desired $\mathrm{pH}$ value, as required, before further experiments.

Pepsin (EC 3.4.23.1) from porcine gastric mucosa with an enzymatic activity of $550 \mathrm{U} / \mathrm{mg}$ of protein was obtained from Sigma-Aldrich. Porcine pepsin (50 $\mathrm{mg})$ was first dissolved in Milli-Q water $(1 \mathrm{~mL} ; 27,500$ $\mathrm{U} / \mathrm{mL}$ ) and was then further diluted in Milli-Q water to obtain 5 pepsin concentrations: 2,750, 1,100, 550, 275 , and $110 \mathrm{U} / \mathrm{mL}$. The diluted pepsin solutions were added to the skim milk samples at a ratio of $1 \mu \mathrm{L}$ per $1 \mathrm{~mL}$ of milk and resulted in final pepsin concentrations of $2.75,1.10,0.550,0.275$, and $0.110 \mathrm{U} / \mathrm{mL}$ of milk. Hydrolysis and aggregation occurred within $2 \mathrm{~h}$ within this range of pepsin concentrations. All other chemicals (analytical grade) were also obtained from Sigma-Aldrich unless otherwise specified.

\section{Measurement of $\mathrm{K}-\mathrm{CN}$ Hydrolysis}

Reverse-phase HPLC was used to quantify para$\kappa-\mathrm{CN}$. A $2-\mu \mathrm{L}$ aliquot of diluted pepsin solution was added into the skim milk samples $(2 \mathrm{~mL})$, which was then immediately transferred into 10 different test tubes, with $0.2 \mathrm{~mL}$ per tube, in a water bath at $37^{\circ} \mathrm{C}$. A HPLC buffer solution (0.8 mL: $6 M$ guanidinium hydrochloride, 0.1 $M$ Bis-Tris, $19.5 \mathrm{~m} M$ DL-dithiothreitol, and $5.37 \mathrm{mM}$ sodium citrate, $\mathrm{pH} 7$ ) was subsequently added into each tube at different time points $(1,2,5$, $10,20,30,50,70,90$, and $120 \mathrm{~min}$ ) to stop the pepsin reaction. Each sample was shaken for $10 \mathrm{~s}$, incubated for $1 \mathrm{~h}$ at room temperature, and centrifuged before HPLC injection.

Reverse-phase HPLC analysis, based on previous methods established by Bonfatti et al. (2013) and Day 
et al. (2015) with some modifications, was carried out using a Nexera-X2 ultra-HPLC instrument equipped with an SPD-M20A diode array detector (Shimadzu). Separation was carried out using a Phenomenex Aeris Widepore XB-C18 column $(100 \mathrm{~mm} \times 4.6 \mathrm{~mm}, 3.6-\mu \mathrm{m}$ particles). The column temperature was maintained at $45^{\circ} \mathrm{C}$ and the detection wavelength was $214 \mathrm{~nm}$. Chromatographic runs were carried out with an injection volume of $10 \mu \mathrm{L}$ at a flow rate of $0.8 \mathrm{~mL} / \mathrm{min}$, with (A) $0.1 \%(\mathrm{vol} / \mathrm{vol})$ trifluoroacetic acid, and (B) acetonitrile containing $0.1 \%$ ( $\mathrm{vol} / \mathrm{vol}$ ) trifluoroacetic acid as solvents. The following solvent gradients were then applied: 0 to $2.5 \mathrm{~min}$, isocratic conditions, $10 \% \mathrm{~B} ; 2.5$ to $22 \mathrm{~min}, 10 \%$ to $49 \% \mathrm{~B} ; 22$ to $23 \mathrm{~min}, 49 \%$ to $10 \% \mathrm{~B}$; 23 to $30 \mathrm{~min}$, isocratic conditions, $10 \% \mathrm{~B}$. The amount of para-k-CN was quantified using LabSolutions Main (Shimadzu Corp.) software based on peak areas.

\section{Measurement of Protein Coagulation}

The coagulation process was carried out in a stresscontrolled rheometer (MCR301 Anton Paar) equipped with Couette geometry (Anton Paar; CC27, with $28.93 \mathrm{~mm}$ cup diameter and $26.64 \mathrm{~mm}$ bob diameter). Milk samples $(17 \mathrm{~mL})$ were equilibrated at $37^{\circ} \mathrm{C}$ for $15 \mathrm{~min}$, then pepsin solution $(17 \mu \mathrm{L})$ was added into the samples, which were stirred for $30 \mathrm{~s}$ before being loaded into the rheometer. A time sweep measurement was carried out at a constant frequency of 0.1 $\mathrm{Hz}$ with a strain of $1 \%$ (within the linear viscoelastic region as determined by strain sweep measurements), and the storage modulus $\left(\mathrm{G}^{\prime}\right)$ was recorded at $37^{\circ} \mathrm{C}$ for 120 min. The $\mathrm{pH}$ measurements started simultaneously after the addition of pepsin in a sample held under the same conditions outside the rheometer, and the $\mathrm{pH}$ was recorded every $1 \mathrm{~min}$.

\section{Microstructural Characterization of Coagulum}

The microstructure of the pepsin-induced coagulum was examined using confocal laser scanning microscopy. Fast Green fluorescent dye $(3 \mu \mathrm{L} ; 1 \% \mathrm{wt} / \mathrm{vol})$ was added to skim milk $(100 \mu \mathrm{L})$ and stirred for $30 \mathrm{~s}$. After prewarming to $37^{\circ} \mathrm{C}$, pepsin was added to the milk, reaching a final pepsin concentration of either 0.550 or $1.10 \mathrm{U} / \mathrm{mL}$ of milk. The milk-pepsin mixture was then transferred to the cavity of a microscope glass slide and covered with a glass coverslip. The coagulum was examined using a Leica TCS SP5 confocal laser scanning microscope (Leica Microsystems) with the temperature set at $37^{\circ} \mathrm{C}$ and with a $63 \times$ magnification lens. The micrographs were captured at different time points after pepsin addition $(16,20,30,40,60,80$, and $120 \mathrm{~min})$.

\section{Statistical Analysis}

Samples were prepared in triplicate and rheological measurements of each sample were carried out in triplicate. Ten time points were examined by reversephase HPLC and 4 of them (1, 10, 50, and $120 \mathrm{~min})$ were examined in triplicate. The ANOVA tests were carried out using Prism 8 (GraphPad Software Inc.) to determine the significance of the differences. Differences were significant at $P<0.05$.

\section{RESULTS AND DISCUSSION}

\section{Kinetics of $\mathrm{k}-\mathrm{CN}$ Hydrolysis by Pepsin}

The degree of hydrolysis of the $\kappa-\mathrm{CN}$ was determined by comparing the peak area of para- $\kappa-\mathrm{CN}$ released at each time point with the peak area of the completely hydrolyzed milk (a sample treated with $2.75 \mathrm{U} / \mathrm{mL}$ pepsin at pH 6.0 for 8 h; Gastaldi et al., 2003; Liu et al., 2014). This is expressed as

$$
H_{t}=100 \times P_{t} / P_{t o t}
$$

where $H_{t}$ is the percent hydrolysis of $\kappa_{-} \mathrm{CN}$ at time $t$, $P_{t}$ is the peak area of para-k-CN released at time $t$, and $P_{\text {tot }}$ is the peak area of para-k-CN for a completely hydrolyzed sample. The $\kappa$-CN peaks almost completely disappeared after holding for a period of $8 \mathrm{~h}$ at $\mathrm{pH}$ 6.0 in the presence of $2.75 \mathrm{U} / \mathrm{mL}$ pepsin (Supplemental Figure S1, https://figshare.com/articles/figure/ supplemental_figures_pdf/17009372/1; Yang, 2021), and this was designated as a sample where complete hydrolysis had taken place. In the presence of pepsin at concentrations of 0.110 to $2.75 \mathrm{U} / \mathrm{mL}$, the degree of hydrolysis of $\mathrm{k}-\mathrm{CN}$ in skim milk at $\mathrm{pH} 6.7$ to 5.3 increased with increasing reaction times, as plotted in Figure 1(a)-(e).

Several models were applied to fit the hydrolysis data. In Figure 2, the black dots represent hydrolysis of $\kappa-\mathrm{CN}$ in skim milk at $\mathrm{pH} 6.0$ when the pepsin concentration was $0.55 \mathrm{U} / \mathrm{mL}$. Both the Michaelis-Menten fitted curve (green dotted curve in Figure 2) and the first-order equation fitted curve (blue dashed-dotted curve in Figure 2) describes the data over the first 20 min of hydrolysis well; however, the deviation was considerable after $\sim 80 \%$ hydrolysis. Therefore, these models were not considered further, and a pseudofirst-order equation was applied instead (Jensen et al., 2015):

$$
H_{t}=H_{120} \cdot\left[1-\exp \left(-K_{2} \cdot t\right)\right]
$$



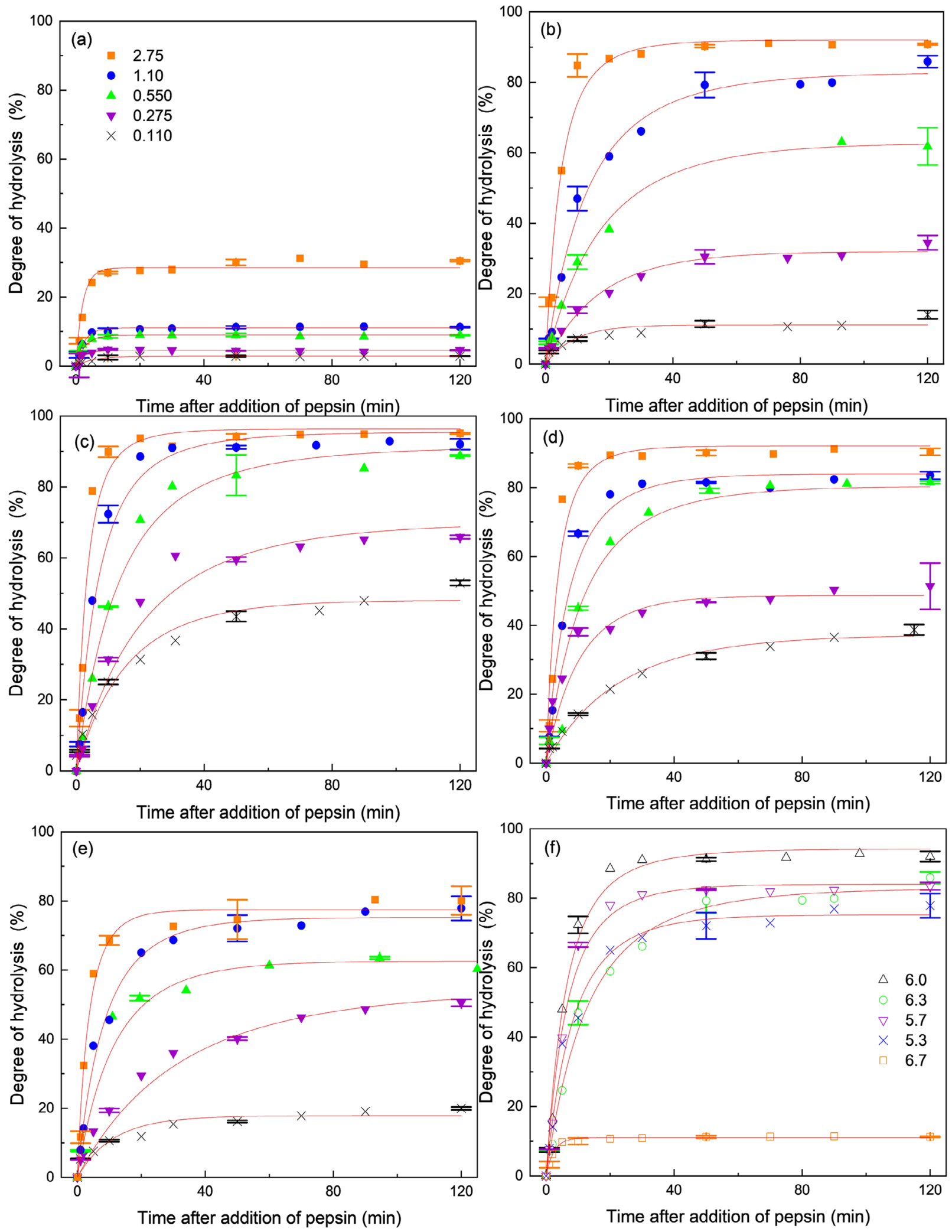

Figure 1. Degree of hydrolysis of $\kappa-\mathrm{CN}$ in skim milk with time after the addition of pepsin $(\boldsymbol{\square} 2.75 \mathrm{U} / \mathrm{mL} ; \mathbf{\bullet} 1.10 \mathrm{U} / \mathrm{mL} ; \boldsymbol{\Delta} 0.550 \mathrm{U} / \mathrm{mL} ; \boldsymbol{\nabla}$ $0.275 \mathrm{U} / \mathrm{mL} ; \times 0.110 \mathrm{U} / \mathrm{mL}$ of milk) at $37^{\circ} \mathrm{C}$ and (a) $\mathrm{pH} 6.7$, (b) pH 6.3, (c) pH 6.0, (d) pH 5.7, and (e) pH 5.3, and (f) degree of hydrolysis of $\kappa$-CN in skim milk with time after the addition of pepsin at $1.10 \mathrm{U} / \mathrm{mL}$ into skim milk at different $\mathrm{pH}$ values $(\square \mathrm{pH} 6.7, \bigcirc \mathrm{pH} 6.3, \Delta \mathrm{pH} 6.0$, $\nabla \mathrm{pH} 5.7, \times \mathrm{pH} 5.3)$. The red solid curves are the fits of equation [3]. Error bars represent SD from triplicate. 


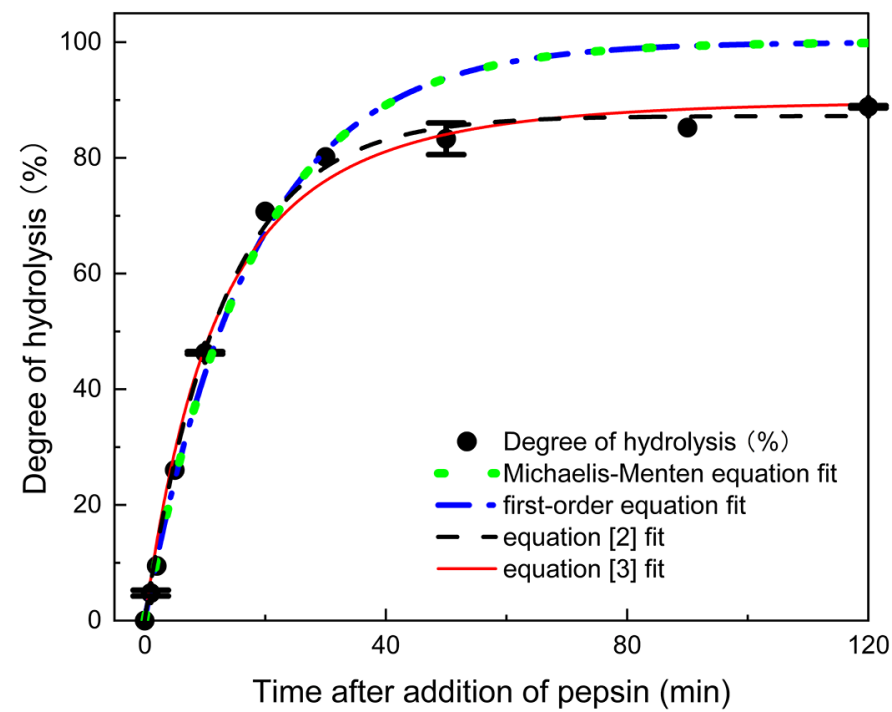

Figure 2. Degree of hydrolysis of $\kappa$-CN in skim milk at $\mathrm{pH} 6.0$ in $120 \mathrm{~min}$ with a pepsin concentration of $0.550 \mathrm{U} / \mathrm{mL}$ (black dots). The green dotted curve is the Michaelis-Menten equation fit, the blue dashed-dotted curve is according to the first-order equation, the black dashed curve is according to equation [2], and the red solid curve is according to equation [3]. Error bars represent SD from triplicate. where $K_{2}\left(\mathrm{~min}^{-1}\right)$ is the reaction rate constant and $H_{120}$ is the degree of hydrolysis of $\kappa-\mathrm{CN}$ at $120 \mathrm{~min}$. With a calculated $K_{2}$ of $0.08 \mathrm{~min}^{-1}$ and an $H_{120}$ of $87 \%$, the fitted curve from equation [2] describes the experimental data points well, as shown by the black dashed curve in Figure 2. $H_{120}$ was lower than $100 \%$, which means that $\kappa-\mathrm{CN}$ was not completely hydrolyzed at $120 \mathrm{~min}$. According to Carlson et al. (1987a), the denaturation of pepsin can occur in parallel with the hydrolysis of $\kappa-\mathrm{CN}$ due to a $\mathrm{pH}$ greater than 5, and denaturation could be complete before there is complete hydrolysis of the $\kappa$-CN. This enzyme denaturation also occurs in chymosin-catalyzed proteolysis of $\kappa-\mathrm{CN}$ according to van Hooydonk (1987), who proposed an overall reaction that was derived from a combination of first-order proteolysis and first-order enzyme denaturation:

$$
\ln \left(\frac{1-H_{t}}{100}\right)=\frac{K_{e n z} \cdot C}{K_{d e n}} \cdot\left[\exp \left(-K_{d e n} \cdot t\right)-1\right]
$$

where $H_{t}$ is the percent hydrolysis of $\kappa$-CN at time $t$, $K_{d e n}\left(\min ^{-1}\right)$ is the reaction rate constant for the dena-

Table 1. Hydrolysis kinetics of $\kappa$-casein in bovine skim milk at different $\mathrm{pH}$ values and pepsin concentrations ${ }^{1}$

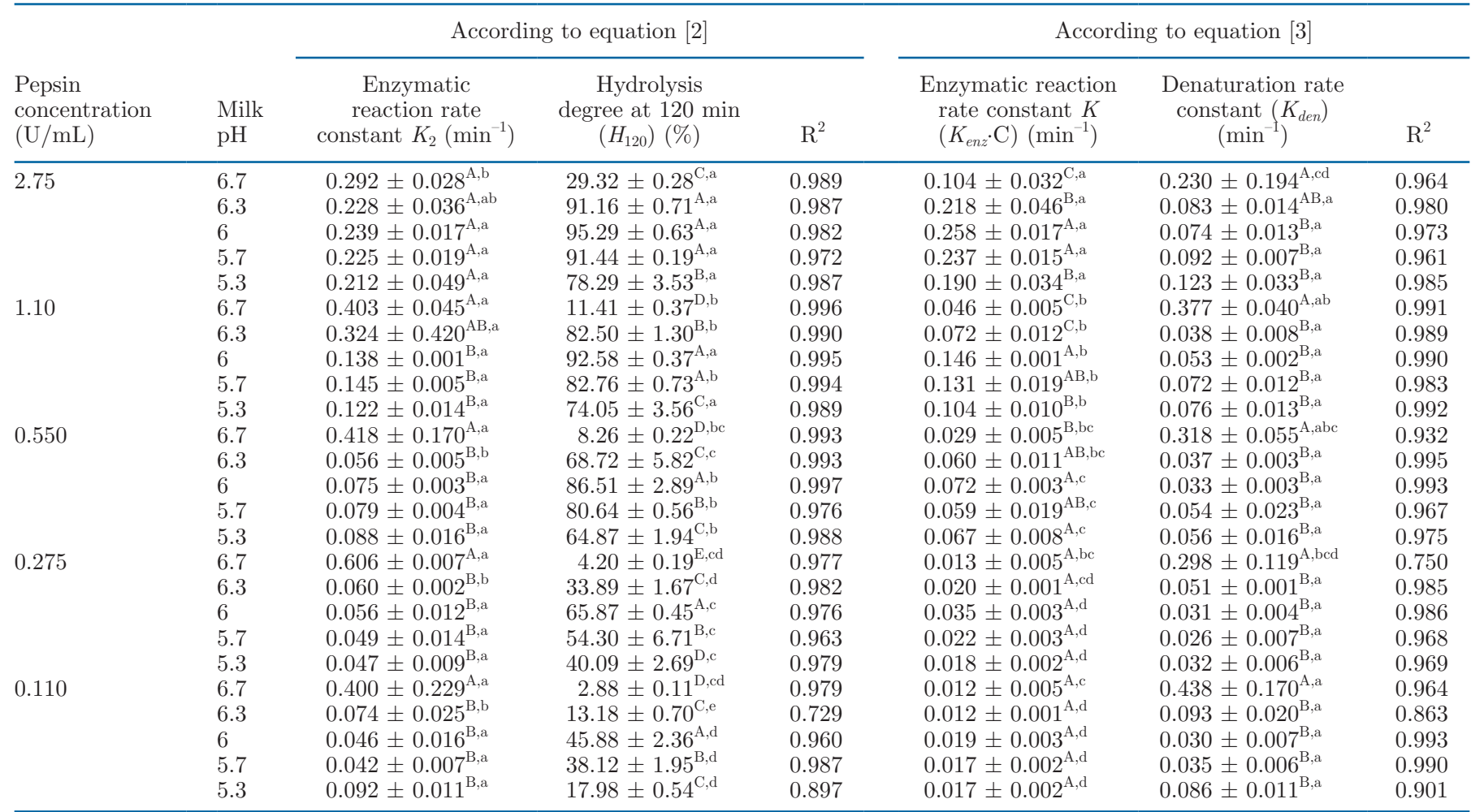

$\overline{\mathrm{A}-\mathrm{E}}$ Mean values between samples at same pepsin concentration in the same column with different superscripts are significantly different $(P<$ $0.05)$.

${ }^{\mathrm{a} e}$ Mean values between samples at same $\mathrm{pH}$ in the same column with different superscripts are significantly different $(P<0.05)$.

${ }^{1}$ Results are expressed as the mean $\pm \mathrm{SD}$ of the mean $(\mathrm{n}=3)$. 


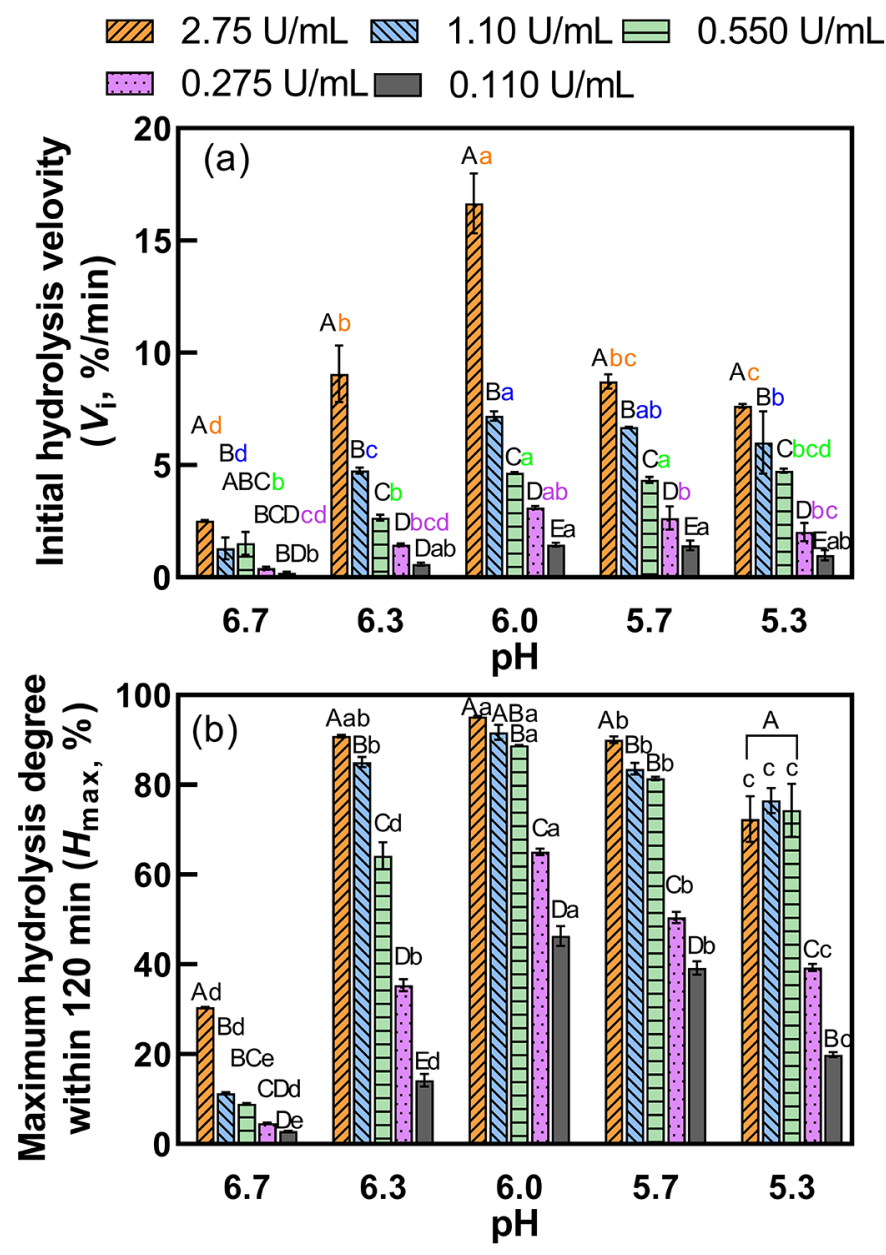

Figure 3. (a) Initial hydrolysis velocity $\left(V_{\mathrm{i}}, \% / \mathrm{min}\right)$ and $(\mathrm{b})$ maximum hydrolysis percent within 120 min for samples at 6.7 to 5.3 when the concentrations of pepsin were 0.110 to $2.75 \mathrm{U} / \mathrm{mL}$ (orange, 2.75 $\mathrm{U} / \mathrm{mL}$; blue, $1.10 \mathrm{U} / \mathrm{mL}$; green, $0.550 \mathrm{U} / \mathrm{mL}$; purple, $0.275 \mathrm{U} / \mathrm{mL}$; and gray, $0.110 \mathrm{U} / \mathrm{mL})$. Mean values between samples at same $\mathrm{pH}$ with different uppercase letters $(\mathrm{A}-\mathrm{E})$ are significantly different $(P<0.05)$. Mean values between samples at same pepsin concentration with different lowercase letters $(\mathrm{a}-\mathrm{e})$ are significantly different $(P<0.05)$. Error bars represent SD from triplicate.

turation reaction, $C(\mathrm{U} / \mathrm{mL})$ is the pepsin concentration, $K_{\text {enz }}\left(\mathrm{min}^{-1} \mathrm{U}^{-1} \mathrm{~mL}\right)$ is the reaction rate constant for the enzymatic reaction per unit quantity of enzyme solution, and $K_{e n z} \cdot C$ is defined as the overall reaction rate constant $K\left(\mathrm{~min}^{-1}\right)$. This equation describes the experimental data well, in which proteolysis and denaturation take place simultaneously, as shown in Figure 2 (red solid curve). Both equations [2] and [3] were used for fitting the data in Figure 1, yielding the parameters shown in Table 1 . However, the $K_{2}$ values cannot reflect the initial hydrolysis velocities $\left[V_{i}(\% / \mathrm{min})\right]$ as determined by linear regression of the first 4 time points of the degree of hydrolysis [Figure 3(a)] as, for example,
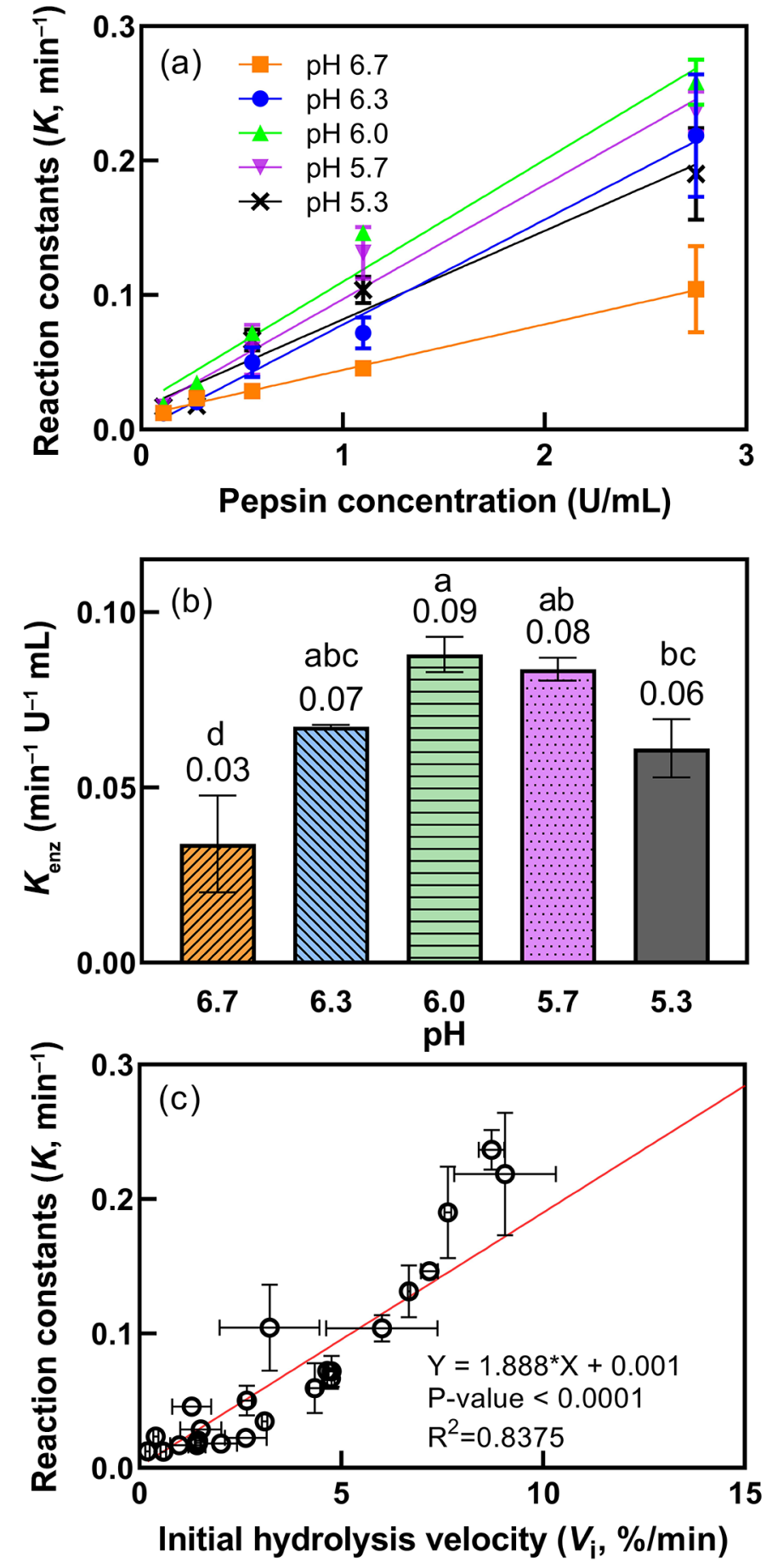

Figure 4. (a) Enzymatic reaction rate constant $K\left(K_{e n z} \cdot C, \min ^{-1}\right)$ as a function of pepsin concentration $(0.110-2.75 \mathrm{U} / \mathrm{mL})$ at $\mathrm{pH}$ $6.7, \bullet \mathrm{pH} 6.3, \boldsymbol{\mathrm { pH }} 6.0, \boldsymbol{\nabla} \mathrm{pH} 5.7$, and $\times \mathrm{pH} 5.3$. (b) $K_{e n z}\left(\mathrm{~min}^{-1} \mathrm{U}^{-1}\right.$ $\mathrm{mL}$ ), calculated from the slopes of the curves in (a) at (orange) $\mathrm{pH}$ 6.7, (blue) $\mathrm{pH} 6.3$, (green) $\mathrm{pH} 6.0$, (purple) $\mathrm{pH} 5.7$, and (gray) $\mathrm{pH} 5.3$. (c) Reaction constants $\left(K, \mathrm{~min}^{-1}\right)$ as a function of the initial hydrolysis velocity $\left(V_{i}, \% / \mathrm{min}\right)$. Mean values with different lowercase letters (a-d) are significantly different $(P<0.05)$. Error bars represent SD from triplicate. 
at $\mathrm{pH} 6.7$, the $V_{i}$ value for the sample at a pepsin concentration of $2.75 \mathrm{U} / \mathrm{mL}$ was higher than that of 1.10 $\mathrm{U} / \mathrm{mL}$, whereas the $K_{2}$ value for the sample at a pepsin concentration of $2.75 \mathrm{U} / \mathrm{mL}$ was $0.292 \pm 0.028$, lower than $0.403 \pm 0.045$ for $1.10 \mathrm{U} / \mathrm{mL}$. Therefore, equation [3] was selected in this study as the best method to calculate the degree of hydrolysis of $\kappa$-CN at specific times during coagulation. For this reason, the degrees of hydrolysis are reported by the red solid curves in Figure 1.

Effect of Pepsin Concentration on the $\mathrm{Hy}$ drolysis of $\kappa-C N$. According to Figure $3(\mathrm{a})$, the $V_{i}$ values increased at higher pepsin concentrations; this is apparent for the samples at all $\mathrm{pH}$ values. The enzymatic reaction rate constant $K\left(K_{e n z} \cdot C, \min ^{-1}\right.$; Table 1) increased as pepsin concentration increased, and there was a positive linear correlation between $K$ and the pepsin concentration [Figure 4(a)], which was found at all $\mathrm{pH}$ values. The slope of the curve, equal to $K_{e n z}$, is shown in Figure 4(b). By plotting the reaction constants $(K)$ as a function of the initial velocities $\left(V_{\mathrm{i}}\right)$ [Figure 4(c)], $K$ was observed to have a proportional relationship to $V_{i}$. This indicates that, at the same $\mathrm{pH}$, higher pepsin concentrations resulted in higher $K$, and thus higher $V_{i}$.

The pepsin denaturation rate constants $\left(K_{\text {den }}\right.$; Table 1) appear to be independent of pepsin concentration at the same $\mathrm{pH}$. The maximum degree of hydrolysis within the 120-min time period $\left(H_{\max }\right)$ decreased with a decrease in pepsin concentration (Figure $3 \mathrm{~b}$ ). For the samples with lower hydrolysis reaction constants $K$ where pepsin concentration is lower, a lower maximum degree of hydrolysis $\left(H_{\max }\right)$ in the 120-min time period was observed.

Effect of $p H$ on the Hydrolysis of $\kappa-C N$. As shown in Figure 3(b), $H_{\max }$ values over 120 min were below $100 \%$. According to van Hooydonk (1987), $\kappa-C N$ cannot be totally hydrolyzed by chymosin because of the denaturation of this enzyme at $\mathrm{pH}>7.0$; however, $K_{\text {den }}>0$ reported in this study indicates that denaturation of pepsin occurred at all $\mathrm{pH}$ values (6.7-5.3). Even though the optimum $\mathrm{pH}$ for milk-clotting activity (specific hydrolysis activity) of pepsin is unknown (Andrén, 2011), the milk-clotting activity of porcine pepsin is more $\mathrm{pH}$ dependent than chymosin. Andrén (2011) reported that the porcine pepsin is sensitive to inactivation that denatures rapidly at $\mathrm{pH} \sim 6.5$ and temperature $\sim 30^{\circ} \mathrm{C}$ (when used for cheesemaking), and only $50 \%$ of its milk-clotting activity remains after 1 h. Consequently, denaturation of pepsin could have occurred in the $\mathrm{pH}$ range of 6.7 to 5.3 in this study.

The hydrolysis processes at $\mathrm{pH} 6.7$ to 5.3 in the presence of pepsin at a concentration of $1.10 \mathrm{U} / \mathrm{mL}$ are shown in Figure 1(f). The lowest $H_{\max }(11.30 \%)$ found at $\mathrm{pH} 6.7$ may be related to the denaturation of pepsin $\left(K_{d e n}\right)$ which was significantly higher $(P<$ 0.05 ) for the sample at $\mathrm{pH} 6.7$ compared with other $\mathrm{pH}$ values (Table 1 ). In addition, the sample at $\mathrm{pH} 6.7$ had lower $K$ values [Table 1, Figure 4(a)], $V_{i}$ values [Figure 3(a)] and $K_{\mathrm{enz}}$ values [Figure 4(b)]. As both the casein micelles (pI 4.6) and pepsin (pI 2.7) are negatively charged in the $\mathrm{pH}$ range 6.7 to 5.3 (Herriott et al., 1940; McMahon and Brown, 1984), a decrease in $\mathrm{pH}$ increases the ionic strength (due to the dissolution of colloidal calcium phosphate (CCP) from the casein micelles to the soluble phase) and diminishes the electrostatic repulsion between the casein micelles and pepsin, and thus promotes the binding of pepsin to casein micelles, resulting in faster enzymatic hydrolysis and higher $K_{e n z}$ (van Hooydonk, 1987). $K_{e n z}$ was highest for the sample at $\mathrm{pH} 6.0$ [Figure 4(b)], which indicates that the optimal $\mathrm{pH}$ for pepsin-induced hydrolysis of $\kappa-\mathrm{CN}$ is $\mathrm{pH} 6.0$, similar to that for chymosin-induced hydrolysis (van Hooydonk, 1987). With minimum voluminosity of the casein micelles at $\mathrm{pH}$ near 6.0 and maximum voluminosity at $\mathrm{pH}$ around 5.3, van Hooydonk (1987) proposed that the accessibility of the $\kappa-\mathrm{CN}$ $\mathrm{Phe}^{105}-\mathrm{Met}^{106}$ bond for chymosin might be a function of the protrusion of the caseinomacropeptide part of $\kappa$-CN into the serum, which may also be the case for pepsin accessibility. The protrusion of caseinomacropeptide is probably minimal at $\mathrm{pH}$ close to 6.0 due to the minimum voluminosity of casein micelles at this $\mathrm{pH}$, diminishing steric hindrance and creating a higher probability for an effective interaction between pepsin and к-CN (van Hooydonk, 1987). In the other side, pepsin diffusion probably decreases and consequently decrease in $K_{e n z}$ when casein micelles aggregate and form a gel. Since the aggregation of casein micelles occurs at lower degree of hydrolysis at lower $\mathrm{pH}$, the effect of a limited diffusion of pepsin would be observed earlier at lower $\mathrm{pH}$. These 2 opposite effects on $K_{\text {enz }}$ could also explain an optimal $\mathrm{pH}$ for pepsin-induced hydrolysis of $\kappa-\mathrm{CN}$ at $\mathrm{pH} 6.0$.

\section{Pepsin-Induced Milk Coagulation}

The increase in the storage modulus $\left(\mathrm{G}^{\prime}\right)$ of skim milk after the addition of pepsin is shown in Figure $5(\mathrm{a})-(\mathrm{e})$, representing the samples at $\mathrm{pH}$ values 6.7 to 5.3 (the loss modulus, G", was also recorded, and Supplemental Figure S2 (https://figshare.com/ articles/figure/supplemental_figures_pdf/17009372/1; Yang, 2021) shows the change in $\mathrm{G}^{\prime}$ and $\mathrm{G}^{\prime \prime}$ over time for skim milk at $\mathrm{pH} 6.0$ after the addition of pepsin at concentrations of $0.550 \mathrm{U} / \mathrm{mL}$ ). Except for samples 
at $\mathrm{pH}$ 6.7, the $\mathrm{G}^{\prime}$ versus time curves showed 3 stages, depending upon the concentration of pepsin and the $\mathrm{pH}$ : (1) in the early stages of coagulation, the sample was still in liquid phase that $\mathrm{G}^{\prime}$ showed a lag phase; (2) as time progressed, $G^{\prime}$ increased significantly with increasing hydrolysis time; (3) in the later stages, $\mathrm{G}^{\prime}$ reached a plateau for the samples at $\mathrm{pH} 6.3$ [Figure $5(\mathrm{~b})]$ or decreased for the samples at $\mathrm{pH}$ values 6.0 to 5.3 [Figure 5(c)-(e)]. For the second stage, after hydrolysis of $\kappa-\mathrm{CN}$, steric repulsion due $\kappa-\mathrm{CN}$ is reduced and the destabilized para-CN micelles aggregate via hydrophobic interactions, leading to the formation of a casein network (Panthi et al., 2019). Calcium and hydrogen bonds also contribute to the specificity and stability of protein interactions (Lefebvre-Cases et al., 1998). According to Mellema et al. (2002) and Panthi et al. (2019), due in part to the rearrangement, movement of casein micelles or clusters by detaching at weak bonds at one junction and connecting to another junction eventually leads to increased strength of the bonds. In addition, the protein network density between para-CN micelles increases over time, which results in the observed increase in $\mathrm{G}^{\prime}$ (Panthi et al., 2019). The time point at which coagulation occurs has previously been defined as the point when $\mathrm{G}^{\prime}$ is equal to $\mathrm{G}^{\prime \prime}$ ( $\mathrm{Li}$ and Dalgleish, 2006) or the point at which $\mathrm{G}^{\prime}$ is greater than $1 \mathrm{~Pa}$ (Meletharayil et al., 2015). Panthi et al. (2019) took the first consistent increase in $G^{\prime}$ as the coagulation time, which is more precise than previous methods. In this study, as shown in the inset of Figure $5(\mathrm{~d})$, a linear regression can be applied to the first 4 points when $\mathrm{G}^{\prime}$ began to increase above the data noise. The coagulation time was defined as the intercept of this regression with the time axis. $G^{\prime}$ increased over time, and the maximum slope of $\mathrm{G}^{\prime}$ as a function of time $\left(\mathrm{dG}^{\prime} / \mathrm{d} t\right)$ is an indication of the curd firming rate (Guinee et al., 1997; Panthi et al., 2019).

Effect of Pepsin Concentration on the Coagulation Process. At pepsin concentrations of 0.110 and $0.275 \mathrm{U} / \mathrm{mL}$, no coagulation occurred within $120 \mathrm{~min}$. Figure 5(c) illustrates the change in $\mathrm{G}^{\prime}$ with time at $\mathrm{pH} 6.0$ after the addition of pepsin at concentrations of $2.75,1.10$, and $0.550 \mathrm{U} / \mathrm{mL}$, where the coagulation times were $\sim 5,11$, and $25 \mathrm{~min}$, respectively [Figure $6(\mathrm{a})]$. The degree of hydrolysis of $\mathrm{k}-\mathrm{CN}$ at the coagulation time (the critical degree of hydrolysis, $H_{c t}$ ) was calculated from $H_{t}$ using equation [3]. Coagulation occurred when $\sim 64 \%, 70 \%$, and $70 \%$ of the $\kappa-\mathrm{CN}$ had been hydrolyzed in the presence of pepsin concentrations of $2.75,1.10$, and $0.550 \mathrm{U} / \mathrm{mL}$ at $\mathrm{pH} 6.0$, respectively [Figure $6(\mathrm{~b})$ ]. For each $\mathrm{pH}$ value, the differences in $H_{c t}$ among different pepsin concentrations were not significant $(P>$ $0.05)$. Therefore, the degree of hydrolysis of $\kappa-\mathrm{CN}$ that is required for coagulation seems to be independent of the pepsin concentration for a fixed $\mathrm{pH}$. In the presence of a higher pepsin concentration $(2.75 \mathrm{U} / \mathrm{mL})$, with a higher reaction rate constant $K$, it took less time to reach the critical degree of hydrolysis $(\sim 68 \%$ at $\mathrm{pH}$ $6.0)$, which explains the shorter coagulation time. In the presence of low pepsin concentrations ( 0.275 and $0.110 \mathrm{U} / \mathrm{mL}$ ), as the maximum degrees of hydrolysis were found to be $<68 \%$ ( $65 \%$ and $46 \%$ for 0.275 and $0.110 \mathrm{U} / \mathrm{mL}$, respectively), no coagulation occurred due to insufficient hydrolysis of $\kappa-\mathrm{CN}$ within $120 \mathrm{~min}$.

As shown in Figure 6(c), higher pepsin concentrations resulted in higher firming rates $\left(\mathrm{dG}^{\prime} / \mathrm{d} t\right)$ at all $\mathrm{pH}$ values. By plotting the firming rates $\left(\mathrm{dG}^{\prime} / \mathrm{d} t\right)$ with the hydrolysis reaction rate constant $(K)$, a proportional relationship was found, as shown in Figure 7. The firming rate in the aggregation phase could be considered as independent of the hydrolysis phase with respect to the different $Q_{10}$ value (defined as the proportional rate of increase in reaction rate as temperature rises by $10^{\circ}$ from $20^{\circ} \mathrm{C}$ to $30^{\circ} \mathrm{C}$ ) of the hydrolysis phase compared with the aggregation phase (Dalgleish, 1979; van Hooydonk, 1987). However, according to Bringe and Kinsella (1986), the curd firming rate is determined not only by para-CN micelle aggregation but also by the initial rate of hydrolysis reaction because of the influence of the enzymatic reaction on aggregation; for example, for the samples at $\mathrm{pH} 6.0$, coagulation occurred when $68 \%$ of the para- $\kappa-\mathrm{CN}$ had been released $\left(H_{c t}\right.$ was $\left.\sim 68 \%\right)$, and further increase in $\mathrm{G}^{\prime}$ requires additional unstable paraCN micelles (the limiting step of $\mathrm{dG}^{\prime} / \mathrm{d} t$ could shift to the further hydrolysis of $\kappa-\mathrm{CN})$. The higher hydrolysis reaction constant $(K)$ at higher pepsin concentrations led to more unstable para-CN micelles over time, and this is shown by the increase in the firming rate (Carlson et al., 1987b).

Effect of $p H$ on the Coagulation Process. When the pepsin concentration was same at $1.10 \mathrm{U} / \mathrm{mL}$, the coagulation time and $\mathrm{G}^{\prime}$ of skim milk differed with change in $\mathrm{pH}(6.7-5.3)$ [Figure $5(\mathrm{f})$ ]. This is also the case for samples at other pepsin concentrations that the effect of $\mathrm{pH}$ on coagulation time and firming rate were compared in Figure 6. As shown in Figure 6(a), the coagulation time decreased as $\mathrm{pH}$ decreased. When the coagulation time was substituted into equation [3], the average $H_{\text {ct }}$ values were $\sim 73,68,57$, and $33 \%$ for the samples at $\mathrm{pH} 6.3,6.0,5.7$, and 5.3, respectively [Figure $6(\mathrm{~b})$ ], noting that $H_{\mathrm{ct}}$ was found to be independent of the pepsin concentration at $0.550 \mathrm{U} / \mathrm{mL}$ and higher. The degree of hydrolysis required for coagulation to occur decreased markedly with a decrease in $\mathrm{pH}$, which was also observed in chymosin-induced milk coagulation (Carlson et al., 1987b,c; van Hooydonk, 

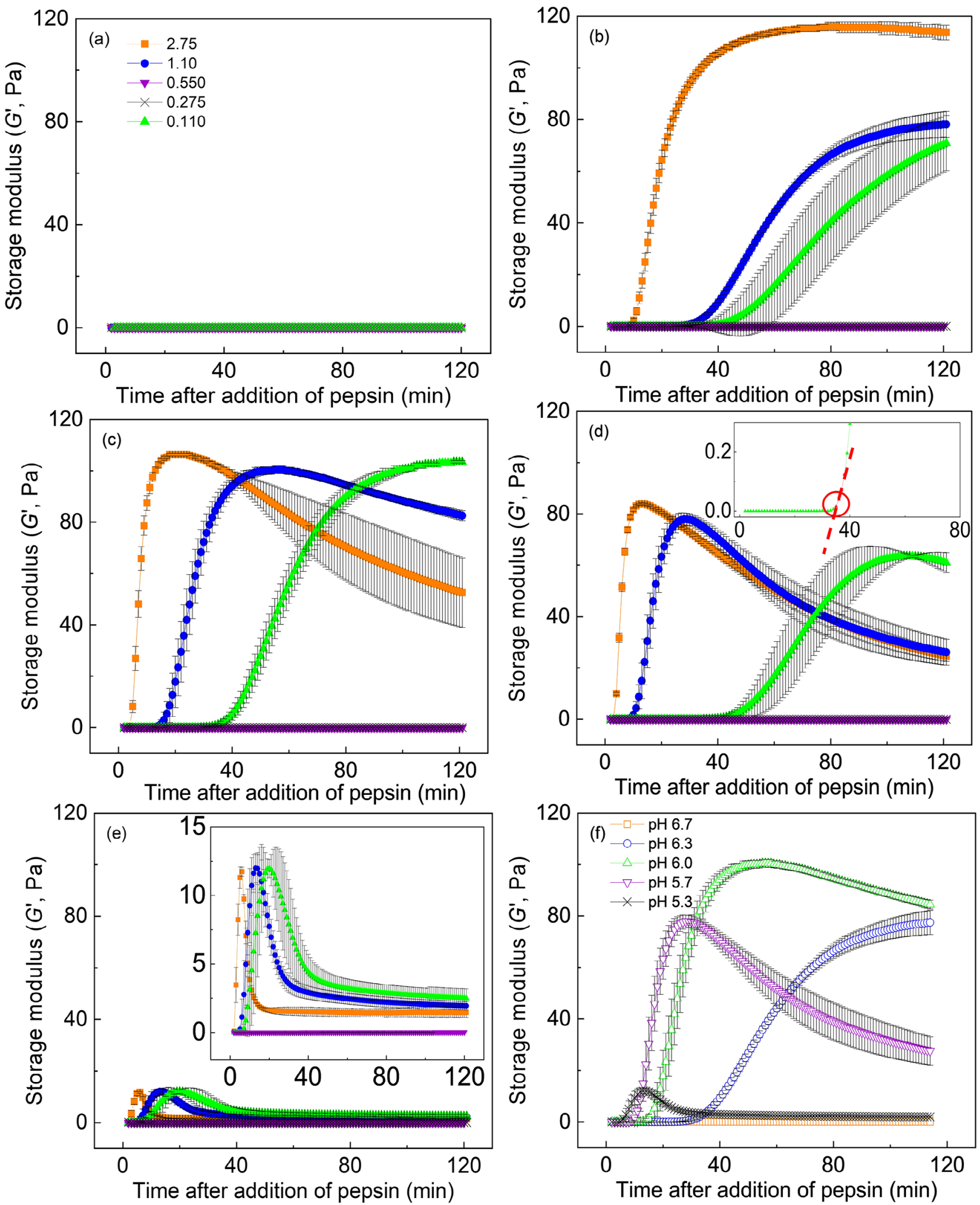

Figure 5. Storage modulus $\left(\mathrm{G}^{\prime}\right)$ of samples as a function of pepsin concentration $(\mathbf{\square} 2.75 \mathrm{U} / \mathrm{mL}, \bullet 1.10 \mathrm{U} / \mathrm{mL}, \boldsymbol{\Delta} 0.550 \mathrm{U} / \mathrm{mL}, \boldsymbol{\nabla} 0.275 \mathrm{U} /$ $\mathrm{mL}$, and $\times 0.110 \mathrm{U} / \mathrm{mL}$ ) at $37^{\circ} \mathrm{C}$ : (a) $\mathrm{pH} 6.7$, (b) $\mathrm{pH} 6.3$, (c) $\mathrm{pH} 6.0$, (d) $\mathrm{pH} 5.7$, with an inset to show coagulation time (details are described in text); and (e) pH 5.3 with zoomed inset. (f) Storage modulus $\left(\mathrm{G}^{\prime}\right)$ of samples over time after the addition of pepsin at a concentration of 1.10

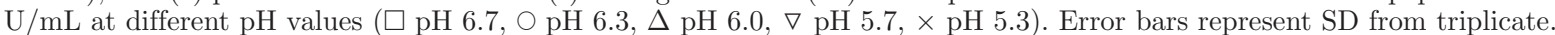


$2.75 \mathrm{U} / \mathrm{mL} 1.10 \mathrm{U} / \mathrm{mL}$ 曰 $0.550 \mathrm{U} / \mathrm{mL}$
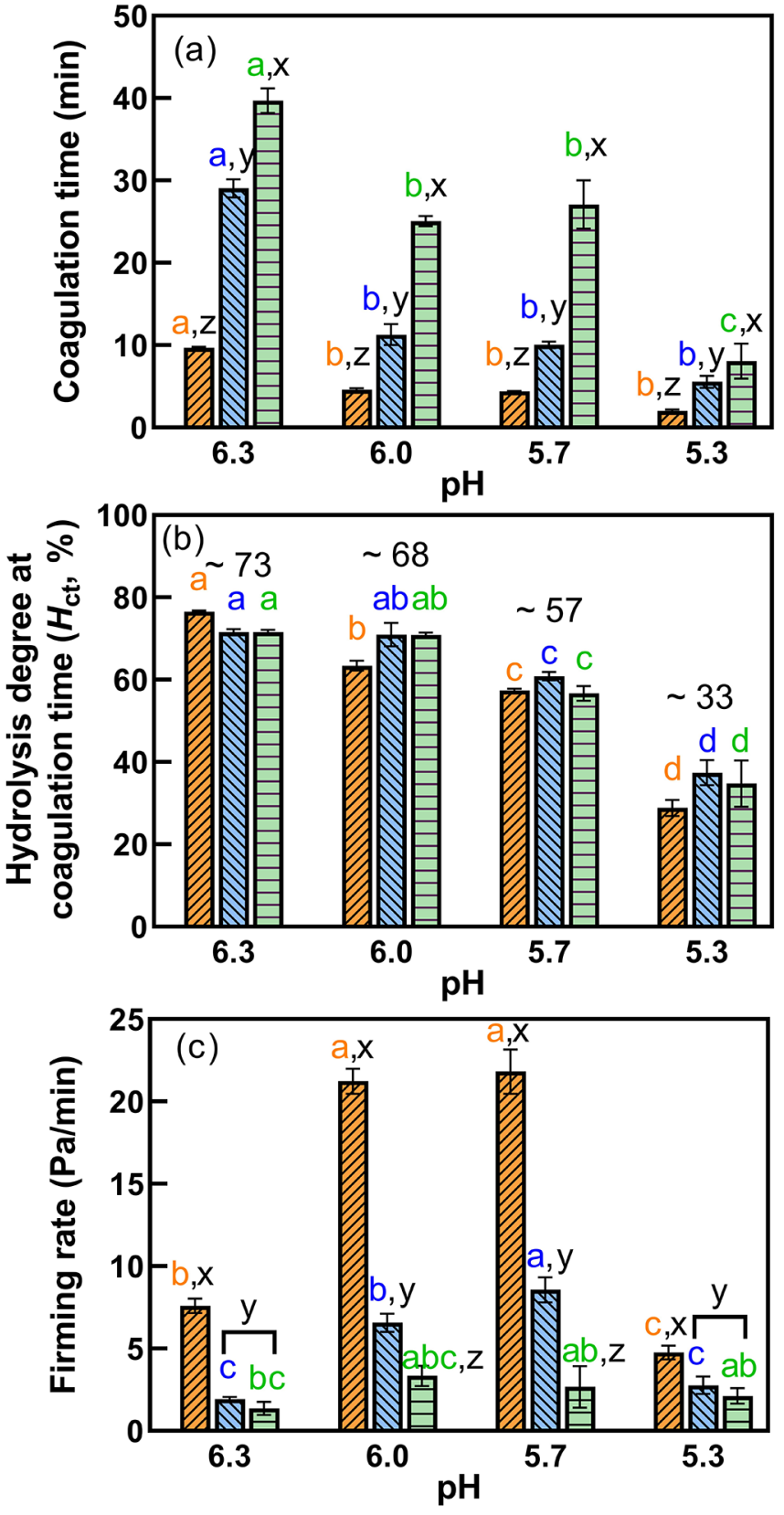

Figure 6. (a) Coagulation time (min), (b) hydrolysis degree at coagulation time $\left(H_{\mathrm{ct}}, \%\right)$, and (c) firming rate $\left(\mathrm{dG}^{\prime} / \mathrm{d} t, \mathrm{~Pa} / \mathrm{min}\right)$ as a function of pepsin concentration $(0.110-2.75 \mathrm{U} / \mathrm{mL})$ at $\mathrm{pH}$ values 6.7 to 5.3: (orange: $2.75 \mathrm{U} / \mathrm{mL}$, blue: $1.10 \mathrm{U} / \mathrm{mL}$, and green: $0.550 \mathrm{U} / \mathrm{mL}$ ). Mean values between samples at same $\mathrm{pH}$ with different uppercase letters $(\mathrm{X}-\mathrm{Z})$ are significantly different $(P<0.05)$. Mean values between samples at same pepsin concentration with different lowercase letters $(\mathrm{a}-\mathrm{d})$ are significantly different $(P<0.05)$. Error bars represent $\mathrm{SD}$ from triplicate.

1987); this was due to partial charge neutralization of the negatively charged para-CN micelles. The decrease in the magnitude of repulsion forces and increased hy-

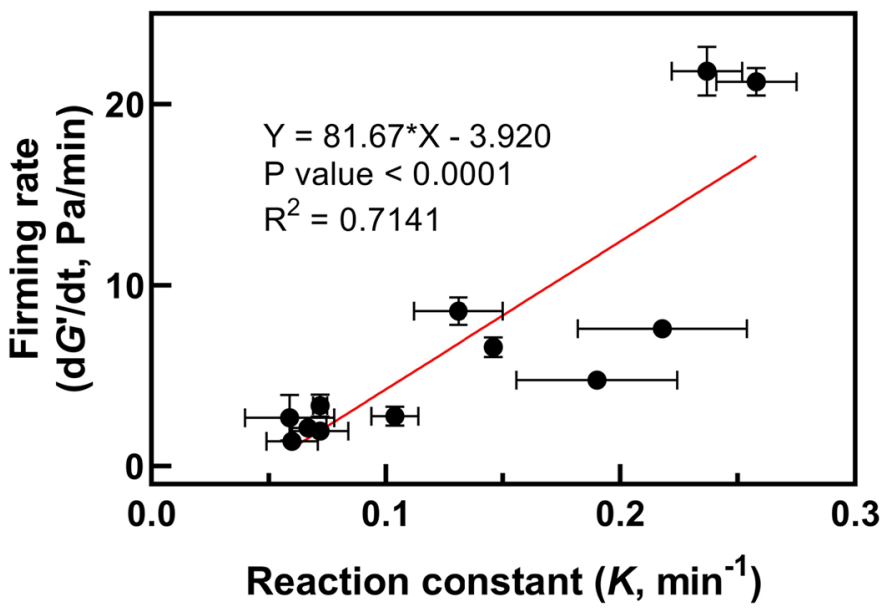

Figure 7. Firming rate $\left(\mathrm{dG}^{\prime} / \mathrm{d} t, \mathrm{~Pa} / \mathrm{min}\right)$ of samples as a function of reaction rate constant $K\left(\mathrm{~min}^{-1}\right)$. Error bars represent SD from triplicate.

drophobic interactions allowed a closer approach of the casein micelles, leading to faster onset of aggregation (van Hooydonk, 1987; Zoon et al., 1988). In addition, as measured by Choi et al. (2007), the CCP content of the casein micelles decreases significantly when the $\mathrm{pH}$ decreases from 6.7 to 5.4 , which results in an increase in the concentration and activity of calcium ions in the milk serum. As calcium ions are critical for aggregation of the casein micelles (Lucey and Fox, 1993), the onset of casein aggregation (as measured by coagulation time) occurred more rapidly, even when the degree of hydrolysis of $\kappa-\mathrm{CN}$ was low. The coagulation time was therefore shorter for milk samples at lower $\mathrm{pH}$.

As shown in Figure 6(c), the firming rates $\left(\mathrm{dG}^{\prime} / \mathrm{d} t\right)$ for samples at $\mathrm{pH} 6.0$ and 5.7 were higher than at $\mathrm{pH}$ 6.3 and 5.3 at the 2 highest pepsin concentrations. As previously mentioned, the firming rate is positively correlated with the reaction rate constant ( $K$; Figure 7 ); therefore, higher firming rates were found for the samples at $\mathrm{pH} 6.0$ and 5.7, which had higher $K$ values (Table 1).

The $\mathrm{G}^{\prime}$ reached a plateau for the sample at $\mathrm{pH} 6.3$ [Figure 5(b)] and decreased for the other samples at $\mathrm{pH}<6.3$ [Figure 5(c)-(e)]. Because pepsin hydrolysis is much less specific than chymosin, there is a possibility that other peptide bond cleavages may occur during the experiments. However, as the $\mathrm{pH}$ in this study did not change during $120 \mathrm{~min}$ (results not shown) and according to the RP-HPLC profile, this hypothesis was excluded. The decrease in $\mathrm{G}^{\prime}$ was probably caused by microsyneresis (Roefs et al., 1990), a shrinkage of the casein curd over time, due to small oscillations of the sample (Zoon et al., 1988), thus eliminating the required adhesion of the coagulum to the rheometer 

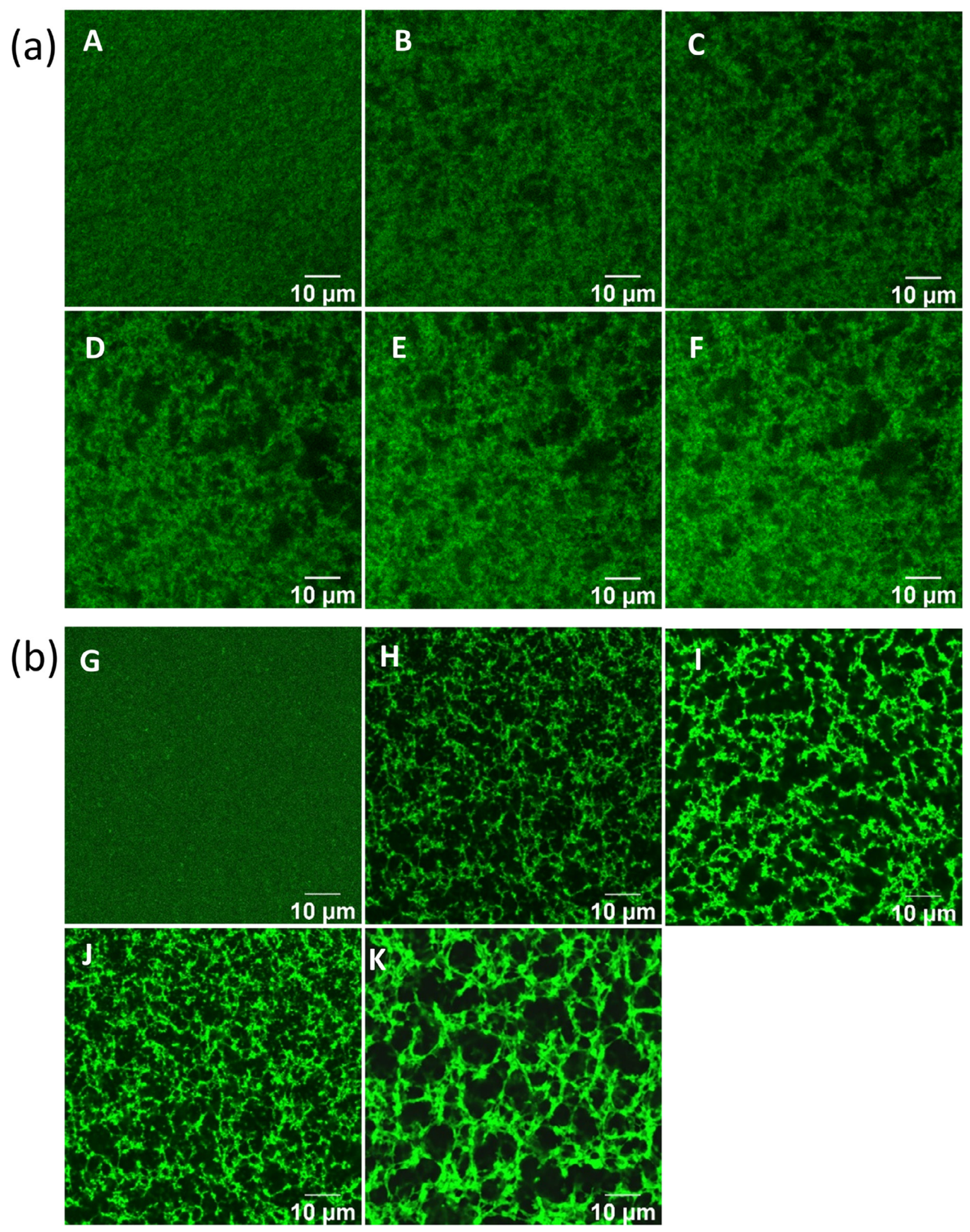

Figure 8. (a) Confocal micrographs at $37^{\circ} \mathrm{C}$ for the pepsin-induced coagulation of milk at (A) $16 \mathrm{~min}$, (B) $20 \mathrm{~min}$, (C) $30 \mathrm{~min}$, (D) $40 \mathrm{~min}$, (E) $60 \mathrm{~min}$, and (F) $80 \mathrm{~min}$ (skim milk pH 6.0 with the addition of pepsin at a concentration of $0.550 \mathrm{U} / \mathrm{mL}$ ); the micrographs were captured at the same position. (b) Microstructures of the coagulum after 120 min with the addition of pepsin at a concentration of $1.10 \mathrm{U} / \mathrm{mL}$ and at $(\mathrm{G})$ $\mathrm{pH} 6.7,(\mathrm{H}) \mathrm{pH} 6.3$, (I) $\mathrm{pH} 6.0,(\mathrm{~J}) \mathrm{pH} 5.7$, and $(\mathrm{K}) \mathrm{pH}$ 5.3. The scale bars are $10 \mu \mathrm{m}$ for all micrographs. 
surface during measurements. Therefore, the value of $\mathrm{G}^{\prime}$ likely does not accurately reflect the coagulum strength at low $\mathrm{pH}$ at longer coagulation times. Further research using nondestructive structural characterization techniques, such as small angle neutron scattering, may provide more information (Gilbert, 2019).

\section{Microstructure of Pepsin-Induced Milk Coagulum}

Confocal micrographs of the coagulum formed from skim milk with a pepsin concentration of $0.550 \mathrm{U} / \mathrm{mL}$ at $\mathrm{pH} 6.0$ are shown in Figure 8(a); the proteins appear as green and the associated pores in the aqueous phase appear as black. In the initial stage of coagulation $(\sim 16 \mathrm{~min})$, the proteins were evenly distributed and homogeneous, indicating that the casein micelles had not yet coagulated. A protein network with some voids and large aggregated structures was observed from $\sim 20$ min. The pores in the matrix became larger (diameter $>20 \mu \mathrm{m})$ and the network became closely knitted with an increase in the reaction time.

The microstructures of the coagulum after a prolonged incubation of $120 \mathrm{~min}$ at $37^{\circ} \mathrm{C}$ are shown in Figure 8(b). As coagulation did not occur for the sample at $\mathrm{pH}$ 6.7, no protein network was observed at 120 min. The observed network structure and the pore size within samples at $\mathrm{pH}$ values of $6.3,6.0$, and 5.7 were similar, whereas the pores observed within the sample at $\mathrm{pH} 5.3$ were larger than in the samples at other $\mathrm{pH}$ values. This observation is consistent with observations of rennet curd at different $\mathrm{pH}$ by Ong et al. (2013). As previously mentioned, $\mathrm{G}^{\prime}$ for the sample at $\mathrm{pH} 5.3$ decreased in the later stages because of curd syneresis. The rearrangement of the casein micelle network at $\mathrm{pH}$ 5.3 appears more extensive and syneresis would likely be more pronounced (Mellema et al., 2002).

\section{CONCLUSIONS}

The pepsin-induced hydrolysis of $\kappa$-CN followed a combined kinetic model of first-order hydrolysis and pepsin denaturation, depending on both pepsin concentration and $\mathrm{pH}$. The rate of hydrolysis increased with the pepsin concentration and was $\mathrm{pH}$ dependent, reaching a maximum velocity at $\mathrm{pH}$ 6.0. Coagulation of the casein micelles occurred when a critical amount of $\kappa$-CN had been hydrolyzed. At a given $\mathrm{pH}$, the critical degree of hydrolysis was independent of the pepsin concentration. The degree of $\kappa-\mathrm{CN}$ hydrolysis required for coagulation decreased markedly from $\sim 73$ to $\sim 33 \%$ when the $\mathrm{pH}$ decreased from 6.3 to 5.3 , likely due to the lower $\mathrm{pH}$ promoting aggregation of casein micelles through neutralization of surface charges and releas- ing $\mathrm{Ca}^{2+}$ by $\mathrm{CCP}$ dissolution. The coagulation time decreased with an increase in pepsin concentration and a decrease in $\mathrm{pH}$. These results suggest that changes in $\mathrm{pH}$ and pepsin concentration markedly affect the hydrolysis of $\kappa-\mathrm{CN}$, the milk coagulation behavior, and the coagulum properties. The knowledge obtained from this study provides further understanding of the observation on the coagulation of milk occurring at the initial stage of gastric digestion in previous in vitro and in vivo studies, which is high $\mathrm{pH}$ and low pepsin concentration.

\section{ACKNOWLEDGMENTS}

This study was funded by New Zealand Milks Mean More (NZ3M) program and Riddet Institute Centre of Research Excellence, Tertiary Education Commission, Palmerston North, New Zealand. The author Mengxiao Yang thanks the Australian Institute of Nuclear Science and Engineering (AINSE, Lucas Heights, New Zealand) for a Post Graduate Research Award. We acknowledge the support of Michael Agnew (AgResearch Limited, Palmerston North, New Zealand) for training in reverse-phase HPLC, Michelle Tamehana (Massey University, Palmerston North, New Zealand) for training in rheometric studies, and Matthew Savoian (Manawatu Microscopy and Imaging Centre, Palmerston North, New Zealand) for training in confocal laser scanning microscopy. We thank Claire Woodhall (Havelock North, New Zealand) for proofreading the manuscript. The authors have not stated any conflicts of interest.

\section{REFERENCES}

Andrén, A. 2011. Cheese: Rennets and coagulants. Pages 574-578 in Encyclopedia of Dairy Sciences: 2nd ed. https://doi.org/10.1016/ B978-0-12-374407-4.00069-8.

Auty, M. A. E., M. A. Fenelon, T. P. Guinee, C. Mullins, and D. M. Mulvihill. 1999. Dynamic confocal scanning laser microscopy methods for studying milk protein gelation and cheese melting. Scanning 21:299-304. https://doi.org/10.1002/sca.4950210503.

Boirie, Y., M. Dangin, P. Gachon, M. P. Vasson, J. L. Maubois, and B. Beaufrère. 1997. Slow and fast dietary proteins differently modulate postprandial protein accretion. Proc. Natl. Acad. Sci. USA 94:14930-14935. https://doi.org/10.1073/pnas.94.26.14930.

Bonfatti, V., M. Giantin, R. Rostellato, M. Dacasto, and P. Carnier. 2013. Separation and quantification of water buffalo milk protein fractions and genetic variants by RP-HPLC. Food Chem. 136:364367. https://doi.org/10.1016/j.foodchem.2012.09.002.

Bringe, N. A., and J. E. Kinsella. 1986. Influence of calcium chloride on the chymosin-initiated coagulation of casein micelles. J. Dairy Res. 53:371-379. https://doi.org/10.1017/S0022029900024997.

Carlson, A., C. G. Hill, and N. F. Olson. 1987a. Kinetics of milk coagulation: I. The kinetics of kappa casein hydrolysis in the presence of enzyme deactivation. Biotechnol. Bioeng. 29:582-589. https://doi .org/10.1002/bit.260290507.

Carlson, A., C. G. Hill, and N. F. Olson. 1987b. Kinetics of milk coagulation: II. Kinetics of the secondary phase: micelle floccula- 
tion. Biotechnol. Bioeng. 29:590-600. https://doi.org/10.1002/bit .260290508 .

Carlson, A., C. G. Hill, and N. F. Olson. 1987c. The kinetics of milk coagulation: IV. The kinetics of the gel-firming process. Biotechnol. Bioeng. 29:612-624. https://doi.org/10.1002/bit.260290510.

Chaplin, B., and M. L. Green. 1980. Determination of the proportion of k-casein hydrolysed by rennet on coagulation of skim-milk. J. Dairy Res. 47:351-358. https://doi.org/10.1017/S0022029900021245.

Choi, J., D. S. Horne, and J. A. Lucey. 2007. Effect of insoluble calcium concentration on rennet coagulation properties of milk. J. Dairy Sci. 90:2612-2623. https://doi.org/10.3168/jds.2006-814.

Dalgleish, D. G. 1979. Proteolysis and aggregation of casein micelles treated with immobilized or soluble chymosin. J. Dairy Res. 46:653-661. https://doi.org/10.1017/S0022029900020719.

Dalgleish, D. G. 1980. A mechanism for the chymosin-induced flocculation of casein micelles. Biophys. Chem. 11:147-155. https://doi .org/10.1016/0301-4622(80)80017-2.

Dalgleish, D. G. 1988. A new calculation of the kinetics of the renneting reaction. J. Dairy Res. 55:521-528. https://doi.org/10.1017/ S002202990003329X

Day, L., R. P. W. Williams, D. Otter, and M. A. Augustin. 2015. Casein polymorphism heterogeneity influences casein micelle size in milk of individual cows. J. Dairy Sci. 98:3633-3644. https://doi .org/10.3168/jds.2014-9285.

Everett, D. W., and M. A. E. Auty. 2008. Cheese structure and current methods of analysis. Int. Dairy J. 18:759-773. https://doi.org/10 .1016/j.idairyj.2008.03.012.

Gao, K. P., T. Mitsui, K. Fujiki, H. Ishiguro, and T. Kondo. 2002. Effect of lactase preparations in asymptomatic individuals with lactase deficiency-gastric digestion of lactose and breath hydrogen analysis. Nagoya J. Med. Sci. 65:21-28. https://doi.org/10.18999/ nagjms.65.1-2.21.

Gastaldi, E., N. Trial, C. Guillaume, E. Bourret, N. Gontard, and J. L. Cuq. 2003. Effect of controlled $\kappa$-casein hydrolysis on rheological properties of acid milk gels. J. Dairy Sci. 86:704-711. https://doi .org/10.3168/jds.S0022-0302(03)73650-9.

Gilbert, E. P. 2019. Small-angle X-ray and neutron scattering in food colloids. Curr. Opin. Colloid Interface Sci. 42:55-72. https://doi .org/10.1016/j.cocis.2019.03.005.

Guinee, T. P., C. B. Gorry, D. J. O'Callaghan, B. T. O'Kennedy, N O'Brie, and M. A. Fenelon. 1997. The effects of composition and some processing treatments on the rennet coagulation properties of milk. Int. J. Dairy Technol. 50:99-106. https://doi.org/10.1111/ j.1471-0307.1997.tb01747.x.

Haug, A., A. T. Høstmark, and O. M. Harstad. 2007. Bovine milk in human nutrition-A review. Lipids Health Dis. 6:25. https://doi .org/10.1186/1476-511X-6-25.

Herriott, R. M., V. Desreux, and J. H. Northrop. 1940. Electrophoresis of pepsin. J. Gen. Physiol. 23:439-447. https://doi.org/10.1085/ jgp.23.4.439

Horne, D. S., and J. A. Lucey. 2014. Revisiting the temperature dependence of the coagulation of renneted bovine casein micelles. Food Hydrocoll. 42:75-80. https://doi.org/10.1016/j.foodhyd.2013 .12 .021 .

Huppertz, T., and L. W. Chia. 2021. Milk protein coagulation under gastric conditions: A review. Int. Dairy J. 113:104882. https://doi .org/10.1016/j.idairyj.2020.104882.

Jensen, H. B., K. S. Pedersen, L. B. Johansen, N. A. Poulsen, M. Bakman, D. E. W. Chatterton, and L. B. Larsen. 2015. Genetic variation and posttranslational modification of bovine k-casein: Effects on caseino-macropeptide release during renneting. J. Dairy Sci. 98:747-758. https://doi.org/10.3168/jds.2014-8678.

Lefebvre-Cases, E., E. Gastaldi, V. Vidal, S. Marchessau, A. Lagaude, J.-L. Cuq, and B. T. De La Fuente. 1998. Identification of interactions among casein gels using dissociating chemical agents. J. Dairy Sci. 81:932-938. https://doi.org/10.3168/jds.S0022 -0302(98)75653-X

Li, J., and D. G. Dalgleish. 2006. Controlled proteolysis and the properties of milk gels. J. Agric. Food Chem. 54:4687-4695. https://doi .org/10.1021/jf060284s.
Liu, X. T., H. Zhang, F. Wang, J. Luo, H. Y. Guo, and F. Z. Ren 2014. Rheological and structural properties of differently acidified and renneted milk gels. J. Dairy Sci. 97:3292-3299. https://doi .org $/ 10.3168 /$ jds.2013-7568.

Lucey, J. A., and P. F. Fox. 1993. Importance of calcium and phosphate in cheese manufacture: A review. J. Dairy Sci. 76:1714-1724. https://doi.org/10.3168/jds.S0022-0302(93)77504-9.

Lucey, J. A., M. E. Johnson, and D. S. Horne. 2003. Invited review: Perspectives on the basis of the rheology and texture properties of cheese. J. Dairy Sci. 86:2725-2743. https://doi.org/10.3168/jds S0022-0302(03)73869-7.

McMahon, D. J., and R. J. Brown. 1984. Composition, structure, and integrity of casein micelles: A review. J. Dairy Sci. 67:499-512. https://doi.org/10.3168/jds.S0022-0302(84)81332-6.

Meletharayil, G. H., H. A. Patel, and T. Huppertz. 2015. Rheological properties and microstructure of high protein acid gels prepared from reconstituted milk protein concentrate powders of different protein contents. Int. Dairy J. 47:64-71. https://doi.org/10.1016/ j.idairyj.2015.02.005.

Mellema, M., P. Walstra, J. H. J. Van Opheusden, and T. Van Vliet. 2002. Effects of structural rearrangements on the rheology of rennet-induced casein particle gels. Adv. Colloid Interface Sci. 98:2550. https://doi.org/10.1016/S0001-8686(01)00089-6.

Minekus, M., M. Alminger, P. Alvito, S. Ballance, T. Bohn, C. Bourlieu, F. Carrière, R. Boutrou, M. Corredig, D. Dupont, C. Dufour, L. Egger, M. Golding, S. Karakaya, B. Kirkhus, S. Le Feunteun, U. Lesmes, A. Macierzanka, A. Mackie, S. Marze, D. J. McClements, O. Ménard, I. Recio, C. N. Santos, R. P. Singh, G. E. Vegarud, M. S. J. Wickham, W. Weitschies, and A. Brodkorb. 2014. A standardised static in vitro digestion method suitable for food-An international consensus. Food Funct. 5:1113-1124. https://doi.org/ 10.1039/C3FO60702J

Miranda, G., and J. P. Pelissier. 1981. In vivo studies on the digestion of bovine caseins in the rat stomach. J. Dairy Res. 48:319-326. https://doi.org/10.1017/S0022029900021749.

Ong, L., R. R. Dagastine, S. E. Kentish, and S. L. Gras. 2013. The effect of calcium chloride addition on the microstructure and composition of Cheddar cheese. Int. Dairy J. 33:135-141. https://doi .org/10.1016/j.idairyj.2013.03.002.

Panthi, R. R., A. L. Kelly, D. J. O'Callaghan, and J. J. Sheehan. 2019 Measurement of syneretic properties of rennet-induced curds and impact of factors such as concentration of milk: A review. Trends Food Sci. Technol. 91:530-540. https://doi.org/10.1016/j.tifs.2019 .07 .023

Payens, T. A. 1979. Casein micelles: the colloid-chemical approach. J. Dairy Res. 46:291-306. https://doi.org/10.1017/ S0022029900017209.

Roefs, S. P. F. M., A. E. A. De Groot-Mostert, and T. van Vliet. 1990. Structure of acid casein gels 1. Formation and model of gel network. Colloids Surf. 50:141-159. https://doi.org/10.1016/0166 $-6622(90) 80259-7$

Roy, D., A. Ye, P. J. Moughan, and H. Singh. 2020. Gelation of milks of different species (dairy cattle, goat, sheep, red deer, and water buffalo) using glucono- $\delta$-lactone and pepsin. J. Dairy Sci. 103:5844-5862. https://doi.org/10.3168/jds.2019-17571.

Sandra, S., M. Alexander, and D. G. Dalgleish. 2007. The rennet coagulation mechanism of skim milk as observed by transmission diffusing wave spectroscopy. J. Colloid Interface Sci. 308:364-373. https://doi.org/10.1016/j.jcis.2007.01.021.

van Hooydonk, A. 1987. The renneting of milk: A kinetic study of the enzymic and aggregation reactions. PhD Thesis. Agricultural University, Wageningen, the Netherlands.

van Lieshout, G. A. A., T. T. Lambers, M. C. E. Bragt, and K. A. Hettinga. 2020. How processing may affect milk protein digestion and overall physiological outcomes: A systematic review. Crit. Rev. Food Sci. Nutr. 60:2422-2445. https://doi.org/10.1080/10408398 .2019 .1646703 .

Yang, M. 2021. Supplemental figures.pdf. figshare. Figure. https://doi .org/https://doi.org/10.6084/m9.figshare.17009372.v1. 
Ye, A. 2021. Gastric colloidal behaviour of milk protein as a tool for manipulating nutrient digestion in dairy products and protein emulsions. Food Hydrocoll. 115:106599. https://doi.org/10.1016/j .foodhyd.2021.106599.

Ye, A., J. Cui, D. Dalgleish, and H. Singh. 2016. Formation of a structured clot during the gastric digestion of milk: Impact on the rate of protein hydrolysis. Food Hydrocoll. 52:478-486. https://doi .org/10.1016/j.foodhyd.2015.07.023.

Ye, A., J. Cui, D. Dalgleish, and H. Singh. 2017. Effect of homogenization and heat treatment on the behavior of protein and fat globules during gastric digestion of milk. J. Dairy Sci. 100:36-47. https://doi.org/10.3168/jds.2016-11764.

Zoon, P., T. van Vliet, and P. Walstra. 1988. Rheological properties of rennet-induced skim milk gels. 2. The effect of temperature. Neth. Milk Dairy J. 42:271-294.

\section{ORCIDS}

Mengxiao Yang ๑ https://orcid.org/0000-0002-5837-4326

Aiqian Ye ๑ https://orcid.org/0000-0003-1048-8858

Zhi Yang @ https://orcid.org/0000-0001-8062-5737

David W. Everett (1) https://orcid.org/0000-0001-5094-5123

Elliot Paul Gilbert 우 https://orcid.org/0000-0001-6413-7813

Harjinder Singh (๑) https://orcid.org/0000-0002-8807-3241 